\title{
Ongoing Procedure Agents
}

National Cancer Institute

\section{Source}

National Cancer Institute. Ongoing Procedure Agents. NCI Thesaurus. Code C162329.

An indication or description that a procedure agent administration is continuing. 